\title{
Strengthening the Ubuntu social canopy after the Afrophobic attacks
}

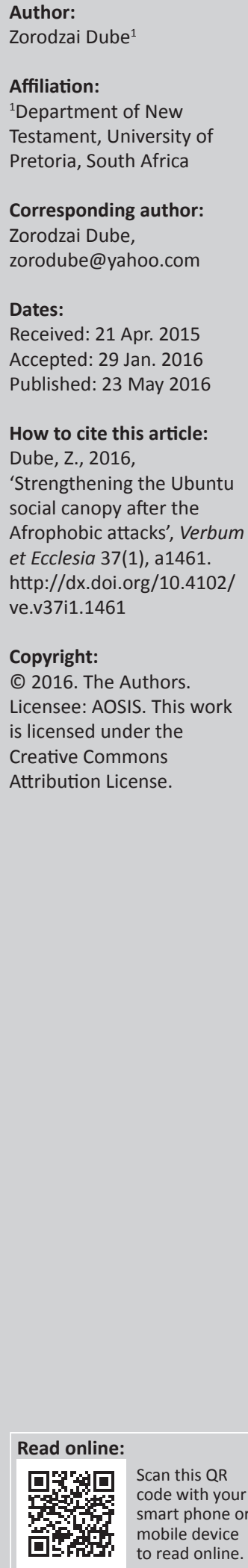

\begin{abstract}
In view of the aftermath of the Afrophobic attacks in South Africa, this study regards Paul's emphasis concerning common humanity and morality as a possible lacuna towards strengthening Ubuntu. Paul taught that both the Jews and the Gentiles have their common ancestor - Adam, and that good morality is a better identity marker than ethnicity. In view of the aftermath of the Afrophobic attacks in South Africa, this study suggests that similar arguments can be used to amend the Ubuntu social canopy.
\end{abstract}

Intradisciplinary and/or interdisciplinary implications: This study is interdisciplinary in nature in that it uses perspectives from social sciences to seek solutions towards a more inclusive community.

\section{Introduction}

The recent (April-May 2015) Afrophobic attacks that spread throughout South Africa received responses of disgust and shame. People across the continent were shocked particularly by the fact that black people were beating and killing fellow black people from countries such as Zimbabwe, Malawi, Nigeria, Ethiopia, Mozambique, and Democratic Republic of Congo. The attacks were described as Afrophobic - hate of fellow black people. The heart-breaking images and news that aired on the national television and radio stations evoked questions such as why do fellow black people attack brothers and sisters from around the continent? Accompanying this question was a sense of shock that a taboo was broken - the collective identity - 'us as Africans', was torn apart. During the attacks, I contributed to the discussion by publishing an article in the local newspaper in which I questioned the whereabouts of the Ubuntu philosophy; a worldview that teaches the interconnectedness of the African people (Dube 2015:n.p). Equally, others, in remorse, wrote in agreement with the former president of South Africa, Thabo Mbeki, saying 'they bow their heads down in shame' (Quintal 2015:n.p). The comments that interested me most were those that say the attacks 'were un-African', 'they divide Africa', and that, 'South Africans are not Africans', 'they are barbaric' (Tshabalala 2015).

What was un-African was the peculiarity of the attacks - fellow black people were killing and attacking fellow black people while sparing the white people and the Indian people. Why were fellow black people attacking only black people, especially those from other African countries? Previous explanations based on the ideas of Frantz Fanon (1963:19; see also Bond 2000:40) explain that such occurrences are caused by economic disparity. People fight among themselves if they have limited resources. Although I acknowledge the strength and validity of such explanations, I choose a different perspective which is informed by the views that the attacks were interpreted as 'un-African' because they tear the Ubuntu social canopy.

\section{Social construction of reality}

Many African communities share a common social worldview - Ubuntu - the belief that one's well-being is intrinsically intertwined with the humanity of others (Tutu 1999:6). Peter Berger and Thomas Luckmann (1966:54) explain that social reality is a reflection of our shared worldviews which functions as a social canopy - thereby giving a sense of order and meaning to all members. Social canopy symbolically expresses our collective values and taboos. In this regard, the family can be regarded as the primary locus of socialisation where members are institutionalised in terms of behaviour through myths, social rewards, and punishment (Berger \& Luckmann 1966:54). The community or the entire village polices the shared values through honour and shame or through the 'public eye' - thereby making sure that the behaviour of all members is in line.

Especially in southern Africa, Ubuntu conceptualises the acceptable ethical character or behaviour. An individual who practices Ubuntu lives according to the expected ideal - 'caring, 
humble, thoughtful, considerate, understanding, wise, generous, hospitable, socially mature, socially sensitive, virtuous, and blessed' (Venter 2004:150). In most Africa societies people are judged based on how they treat and relate to each other. The individual's existence is intertwined with the existence of others, the living and the dead. The individual is the community and vis-à-vis; no individual exists as an island - one's happiness depends on the similar status in others (Tutu 1999:6; Vervliet 2009:20). Colonialism is implicitly accused for bringing an individualistic worldview different from a homogeneous approach to life that is characteristic of most African societies. This does not mean there was no notion of personal responsibility before colonialism; instead the individual was expected to yield, in humility, to the needs and concerns of the others or community. As such, based on the Ubuntu social canopy, the various African regions and countries took it upon themselves to assist fellow Africans in fighting colonialism. For example the Zimbabwean liberation fighters were militarily trained in Tanzania and some in Ghana. The same can be said concerning South Africa which received various kinds of assistance from fellow African countries during their fight against apartheid (Samkange \& Samkange 1980:106).

On a micro level, Ubuntu captures the identity marker; describing what the individual ought to do and or avoid. A person who exhibits the virtues of Ubuntu respects elders and cares for the vulnerable, especially the orphans (Samkange \& Samkange 1980:106). Ubuntu is relational - a person who practices Ubuntu gives dignity to others. A father, mother, son, or daughter are expected to act publicly based on their expected social roles (Wiredu 2008:332; see also Asante 2015).

Desmond Tutu's (Tutu 1999:6) recent publications broaden the definition of Ubuntu to encapsulate God's original intention in creation. Human beings were created to be in harmony with each other, and through Ubuntu, to affirm each other's existence. Thus for Tutu, Ubuntu is our reciprocal; something that all human beings should practice towards each other (Van der Merwe \& Du Plessis 2004:63). It is God's moral philosophy of caring for each other including creation (Tutu 1999:8). By practicing Ubuntu, human beings are interconnected; they are one human race with reciprocal duties towards one another. A person who practices Ubuntu affirms the value of others and does not feel threatened by their success because one's success or failure affects us all (Allen 1997:6; Tutu 1999:12). This is no surprise because Tutu himself is a Christian which may explain why it is easy for him to conflate Ubuntu principles with Christian ideas.

\section{Shift and mutations of the canopy}

Does the attack on fellow Africans suggest a tear into the Ubuntu social canopy? If so, how can we mend the tear? Maybe the first question that needs attention is: do social canopies change? Peter Berger and Thomas Luckmann (1966:40), who studied the effects of secularisation on Europe, note as societies go through various social changes, this also affects their social canopy. Change within the social canopy happens when a social canopy is unable to explain all reality. In this case, the presence of an alternative social reality may influence the original social canopy to shift or accommodate aspects of the new or external canopy. With regards to secularism in Europe, Berger notes the shifts from the religious canopies to a scientised canopy.

Berger and Luckmann's explanation may help us to identify the possible changes across the African continent which affected the Ubuntu canopy. Ubuntu moral philosophy originated from mostly subsistent and less technological African societies. Today such societies are being transformed into urban and technological societies. Concerning this, I identified three issues that may have shifted people's understanding and practice of Ubuntu.

First, the uneven economic developments across the continent which brood disparate national identities can be pinpointed as tearing the previously united people. To explain this, a few developments can be illustrative. After independence, most African countries were divided into separate trading blocs - the Economic Community of West African States (ECOWAS), The East African Community (EAC), Southern African Development Community (SADC), and The Economic Community of Central African States (ECCAS) - a situation which impedes free movement of goods and services within the continent. In some cases this led to wasteful destructive competition within the continent because of lack of cooperation among members (Barnes 2014:n.p). Within the SADC, the choice of South Africa to join the BRICKS, ${ }^{1}$ produced unguarded statements by some politicians and ordinary citizens who now think that South Africa is no longer 'African' or at the same level with the rest of the continent (Barnes 2014:n.p). More importantly, some people may erroneously interpret South Africa's economic strides as reasons to condescendingly look down upon other less advanced African states and their people. For example the president, Jacob Zuma, while addressing business people uttered that, 'we (South Africa) can't think like Africans in Africa - it's not some national road in Malawi', a statement that possibly reveals his nationalistic narcissism (Ephraim 2013:n.p). Zuma's unfortunate statement could be interpreted to mean that the rest of Africa lacks the infrastructural development that characterises South Africa and, in outlook South Africa does not look like the rest of Africa. Thus arguably, variations in economic growth among African states brood destructive competitions among African countries, and in the process erode the Ubuntu that glues the continent together. This reality breeds a conducive climate of xenophobia and sporadic fighting.

Second, capitalism, a market policy adopted by many African states after independence, can be singled out as a contributor in tearing the Ubuntu canopy. Upon the attainment of 1.Refers to Brazil, Russia, India, China and South Africa. 
independence most African countries adopted capitalism, with a view that the free-market economy would allow large corporate companies to emerge and compete with international businesses in attracting more capital to the countries, thereby boosting revenue, production, and gross domestic product. Capitalism shifts attention from the household to the towns as economic hubs. Consequently, a free-market driven economy reorders society from subsistent peasant communities to profit maximisation. This results in the disintegration of African households, kinship ties, and the emergence of individualism. This does not mean that Ubuntu is incompatible with capitalism; instead capitalism shifts the way Ubuntu operates. Ubuntu focuses on reciprocity whereas a market driven economy prioritises profit, individual success, and privatisation. Fearing the possible social changes that may come as a result of capitalism, the late and former president, Mandela (2006:n.p), exhorted people to care for the less fortunate. However, the reality shows that the job of caring for the less fortunate is left to the non-governmental organisations, while the rich people continue to accumulate and parade their wealth. To those who stay in towns Ubuntu seemingly becomes mere rhetoric with little practical implication; people 'do not seem do seek the good of others' and the politicians care less about the needs of the ordinary people besides their vote. It seems true as Bond (2000:69 \& 99), in his book The Elite Transition, says that the attainment of political independence legitimised the racial and class privilege of the minority while the rest continue to suffer.

Third, postmodernity, a worldview that believes that the individual matters more than the community, also shifts the cultural landscape from focusing on the community and family to the individual (Hebdige 1979:90, Kimini 2010:n.p). Within postmodernity the individual becomes more important than the community and laws are channels to protect the rights of the individual. Postmodernity reminds us of the difficulties associated with practicing Ubuntu within an ever-shifting social space, where the individual has no social or moral obligation towards his or her neighbour or community (Hebdige 1979:90).

\section{Strengthening the Ubuntu social canopy}

Given the above challenges, in view of the aftermath of the Afrophobic attacks in South Africa, the study regards Paul's emphasis concerning common humanity and morality as a possible lacuna towards strengthening Ubuntu. This raises the question - why diagnose Ubuntu using ideas from Christianity, a religion known for particularly heinous shortcomings across the continent? The answer is that Christianity has become an African religion; hence we can now talk of African Christianity which signifies that it has blended into the African social canopy (Twesigye 1996:9). I see palpable similarity between the need to curb Afrophobia and Paul's attempt to deal with the Jewish hatred of the Gentiles during the first century. Paul dealt with the challenge by reordering the social canopy. A brief background to this issue may help. Between 37CE and 58CE, Paul presided over the emerging first century Christian movement. The coming of the Gentiles, claiming equal and superior status to the Jews, rattled the Jews who saw the newcomers as unwelcome. The Jews, strongly believing in the idea of election and predestination, refused to open their social boundaries to the Gentiles. They regarded themselves as divinely elected (covenantal nomism) (Dunn 2005:110; Sanders 1977:xxix). In response, in Romans 3:21ff., Paul argued that ethnicity is less important than morality and that both the Jews and Gentiles claim their common humanity from Adam. I use Paul's argument to advocate for a more inclusive social space in South Africa.

Firstly, based on Paul, Ubuntu can be amended and strengthened if focus is placed on the idea that we share our common humanness. Humanity is universal; we are all decedents of Adam, no one is more human or better than others. This argument is clearer in Paul's letters to the Romans and to the Galatians where he states that all humans originate from the same source - Adam. As such the Jews have no special status over the Gentiles ( $R m$ 3:21ff.). Ubuntu also teaches that all people are the same, irrespective of their geography, race, or creed. Thus parochial national geographic identities make us fail to realise that, although geographically distinct, we are all African and fellow human beings (Dube 2014:6).

Secondly, Ubuntu can be amended and reinforced if focus is placed on morality instead of materiality. Comparably, in Galatians 5:22ff., Paul shifted public focus from ethnicity to morality, thereby arguing that both the Jews and the Gentiles need a new identity marker, morality, based on faith in Christ. Therefore Paul argues that, for social cohesion to occur, both the Jews and the Gentiles should have common identity markers of joy, peace, patience, kindness, goodness, faithfulness, gentleness, and self-control. Morality and the best treatment of others are what define Ubuntu. Unfortunately, across Africa there is now a tendency to measure difference by material progress (Hall 1996:185; MacGrew 1996:484). Thus, those who come from across the Limpopo are generally seen as less economically advanced compared to the South Africans (Dube 2014:6). In applying morality as the universal identity marker, it means that morality should replace ethnic and national identities (Gl 5:22). To the Philippians, Paul says, the behaviour associated with being humane is humility (Phlp 1:15-18) and to the Galatians, he exhorted them to love; to exhibit joy, peace, patience, kindness, goodness, faithfulness, gentleness, and self-control; against such things there is no law (Gl 5:22-23). Furthermore, Paul contrasts good morality with what he perceived as inhumane - immorality, impurity, sensuality, idolatry, sorcery, enmities, strife, jealousy, outbursts of anger, disputes, dissensions, factions, envying, drunkenness, and carousing (Gl 5:19-21).

The challenge to this hypothesis is - how do we prioritise morality over materialism? Paul's practical solution was to 
talk and preach about it in Galatia, Rome, Corinth, and elsewhere. Practically today we can say that our media channels should avoid essentialising materialism and nationality; they should be platforms of entrenching morality as our collective identity marker. Habermas (1978) bemoans media for giving a false impression of progress based on paraded materiality, thereby deceiving the people into thinking that being rich is ideal. Arguably, the principles of Ubuntu of love, justice, and peace dovetail with Paul's Christocentric narrative. Morality equals a better society.

\section{Conclusion and remarks}

Paul's emphasis concerning common humanity and morality may be regarded as a possible lacuna towards strengthening the Ubuntu canopy. As society shifts, cardinal pillars should not be eroded. In this regard, and in view of Afrophobia, African communities should be reminded of their common humanity and morality. The public narrative should focus on morality. Our current media (South African Broadcast Cooperation) should cease flaunting material images, deceiving people into thinking that materialism is better than morality. Instead, the media should be a vehicle that teaches people that good morality creates a better society and that material success acquired upon a strong foundation of good morality will benefit all. Borrowing Paul's words, a society that gives more value to materiality instead of morality, is likely to lead into immorality, impurity, sensuality, idolatry, sorcery, enmities, strife, jealousy, outbursts of anger, disputes, dissensions, factions, envying, drunkenness, and carousing (Gl 5:19-21). Equally, a society that focuses on morality over materiality is likely to produce love, joy, peace, patience, kindness, goodness, faithfulness, gentleness, and self-control.

\section{Acknowledgements Competing interests}

The author declares that he has no financial or personal relationships which may have inappropriately influenced the writing of this article.

\section{References}

Allen, J., 1997, The essential: Desmond Tutu, David Phillip, Cape Town.

Asante, M.K., 2015, 'United States of Africa makes Sense', viewed 19 April 2015, from http://www.bdlive.co.za/africa/africanperspectives/2013/04/17/a-united-statesof-africa-makes-sense

Barnes, M., 2014, Straight talk: We want to belong - But not to BRICS, viewed 20 April 2015, from http://www.Bdlive.Co.Za/Opinion/Columnists/2014/07/21/StraightTalk-We-Want-To-Belong--But-To-Brics

Berger, P. \& Luckmann, T., 1966, The social construction of reality: A treatise in the sociology of knowledge, Anchor Books, New York.

Bond, P., 2000, Elite transition from apartheid to neoliberalism in South Africa, Pluto, London.

Dube, Z., 2014, 'The discursive cultural representations of Gentiles: A contextual approach using migration theory', In die Skriflig 48(1), Art. \#1380, 7 pages. http:// dx.doi.org/10.4102/ids.v48i1.1380

Dube, Z., 2015, 'Abstain from pill of self-destruction', PressReader, viewed 25 September 2015, from http://www.pressreader.com/south-africa/pretoria-news /20150420/281754152857715/TextView

Dunn, J., 2005, The new perspective on Paul, Mohr Siebeck, Tubingen.

Ephraim, A., 2013, 'Don't think like Africans in Africa', viewed 19 April 2015, from http:// mg.co.za/article/2013-10-22-zuma-dont-think-like-an-african-pay-up-for-e-tolls.

Fanon, F., 1963, The wretched of the earth, Grove Press, New York.

Habermas, J., 1978, Knowledge and human interests, Heinemann, London.

Hall, S., 1996, The west and the rest: Discourse and power, in S. Hall \& D. Held (eds.), Modernity: An introduction to modern societies, pp. 186-224, Blackwell, Oxford.

Hebdige, D., 1979, Subculture: The meaning of style, Routledge, London.

Kimini, E., 2010, 'Challenges facing nuclear families with the absent fathers in Gatundu North District, Central Kenya', The African Symposium, Vol. 10 (2), pp13-26,

MacGrew, A., 1996, 'A global society', in S. Hall \& D. Held (eds.), Modernity: An introduction to modern societies, pp. 467-497, Blackwell, Oxford.

Mandela, N., 2006, 'Ubuntu', viewed 25 September 2015, from http://www.youtube. $\mathrm{com} /$ watch?v=RKjxgpuymVo

Quintal, G., 2015, 'SA bowing its head in shame, says ANC', News 24, viewed 25 September 2015, from http://www.News24.Com/Southafrica/News/Sa-BowingIts-Head-In-Shame-Says-Anc-20150415

Samkange, J.W.T. \& Samkange, S., 1980, Hunhuism or ubuntuism: A Zimbabwe indigenous political philosophy, Graham Publishing, Harare.

Sanders, E.P., 1977, Paul and the Palestinian Judaism: A comparison of patterns of religion, SPCK, London.

Tshabalala, S., 2015, 'Why black South Africans are attacking foreign Africans but not foreign Whites', Quartz, viewed 25 September 2015, from http://Qz.Com/384041/ Why-Black-South-Africans-Are-Only-Attacking-Foreign-Africans-But-Not-ForeignWhites/

Tutu, D., 1999, No future without forgiveness, Rider, London.

Twesigye, E.K., 1996, African religion, philosophy, and Christianity in Logos-Christ Common ground revisited, Peter Lang Publishing, New York.

Van der Merwe, C.G. \& Du Plessis, J.E. 2004, Introduction to the Law of South Africa, Kluwer Law International, The Hague.

Venter, E., 2004, 'The notion of ubuntu and communalism in African educational discourse', Studies in Philosophy and Education 23, 149-160. http://dx.doi. org/10.1023/B:SPED.0000024428.29295.03

Vervliet, C., 2009, The Human person, African Ubuntu and the dialogue of civilisations, Adonis \& Abbey Publishers Ltd, London.

Wiredu, K., 2008, 'Social philosophy in postcolonial Africa: Some preliminaries concerning communalism and communitarianism', South African Journal of Philosophy 27(4), 332-339. http://dx.doi.org/10.4314/sajpem.v27i4.31522 